\title{
Ichthyouris voltagrandensis n.sp. (NEMATODA: PHARYNGODONIDAE) FROM Myleus tiete EIGENMANN \& NORRIS, 1900 (OSTEICHTHYES: CHARACIDAE) IN THE VOLTA GRANDE RESERVOIR, MG, BRAZIL
}

\author{
MARTINS, M. L., YOSHITOSHI, E. R. and UMEKITA, H. \\ Centro de Aqüicultura, Unesp, Via Prof. Paulo Donato Castellane, km 05, CEP 14870-000, Jaboticabal, SP, Brazil \\ Correspondence to: Maurício Laterça Martins, Centro de Aqüicultura, Unesp, Via Prof. Paulo Donato Castellane, \\ km 05, CEP 14870-000, Jaboticabal, SP, Brazil, e-mail: mlaterca@ caunesp.unesp.br \\ Received January 14, 2000 - Accepted April 25, 2000 - Distributed May 31, 2001
}

(With 10 figures)

\begin{abstract}
The present work studied helminth parasites of "pacu-manteiga", Myleus tiete (Osteichthyes: Characidae) from Volta Grande Reservoir, MG, Brazil. Fishes with $142.6 \pm 24.7 \mathrm{~g}$ weight and $17.3 \pm 1.0 \mathrm{~cm}$ total length were collected. Five out six analysed fish (prevalence $83.3 \%$ ) were parasitized in the intestine with an average of $535.6 \pm 334.6$ oxyurid nematodes per fish. The helminth was identified as Ichthyouris voltagrandensis $\mathrm{n} . \mathrm{sp}$. (Nematoda: Pharyngodonidae). It differs from I. brasiliensis (Moravec et al., 1992a) by the absence of lateral alae, higher measures of tail and caudal alae of males, esophageal isthmus length, distance of excretory pore from anterior end and spicule length. In addition, eggs were provided by two long filaments in just one pole and by the first time the authors observed flagellate spermatozoa from dissected males. The authors exposes comparative table of measures of the five described species of the genus Ichthyouris.
\end{abstract}

Key words: Nematoda, Pharyngodonidae, Ichthyouris voltagrandensis n.sp., Myleus tiete.

\section{RESUMO}

\section{Ichthyouris voltagrandensis n.sp. (Nematoda: Pharyngodonidae) em Myleus tiete} (Osteichthyes: Characidae) do Reservatório de Volta Grande, MG, Brasil

O presente trabalho estudou helmintos parasitos do "pacu-manteiga", Myleus tiete (Osteichthyes: Characidae), do Reservatório de Volta Grande, MG, Brasil, com peso médio de 142,6 \pm 24,7 g e comprimento total médio de 17,3 $\pm 1,0 \mathrm{~cm}$. Cinco, dos seis peixes analisados (prevalência de 83,3\%), estavam parasitados no intestino com média de 535,6 \pm 334,6 nematóides oxiurídeos por peixe. O helminto foi identificado como Ichthyouris voltagrandensis n.sp. (Nematoda: Pharyngodonidae). Difere de I. brasiliensis (Moravec et al., 1992a) por ausência de aleta lateral, maiores dimensões da cauda e da aleta caudal do macho, comprimento do ístmo do esôfago, distância do poro excretor à extremidade anterior e comprimento do espículo. Os ovos são providos de dois longos filamentos situados em apenas um dos pólos e, pela primeira vez, os autores observaram espermatozóides flagelados em machos dissecados. Os autores fornecem tabela comparativa de medidas das cinco espécies do gênero Ichthyouris.

Palavras-chave: Nematoda, Pharyngodonidae, Ichthyouris voltagrandensis n.sp., Myleus tiete.

\section{INTRODUCTION}

There are four described species of genus Ichthyouris Inglis, 1962, an oxyurid nematode parasitizing fishes. Inglis (1962) described I. ro from the intestine of Cichlasoma festivum at Sofia, Georgetown, British Guiana. Moravec \& Prouza (1995) studied I. bursata from Symphysodon discus, an aquarium fish in South Bohemia, Czech Republic. 
In Brazil, Moravec et al. (1992b) reported the presence of $I$. brasiliensis from armoured catfish Pterigoplichthys aculeatus in Paraná River, Guaíra, Paraná State. Nevertheless, Moravec et al. (1992a) described I. laterifilamenta from doradid fish Trachydoras paraguayensis in the hydroelectric power station of Itaipu, Foz do Iguaçu, Paraná State.

In the present work, the authors describes a new species of Ichthyouris collected in the intestine of Myleus tiete (Osteichthyes: Characidae) from Volta Grande Reservoir, MG, Brazil. This is the first record of the nematode genus in the Minas Gerais State.

\section{MATERIAL AND METHODS}

During a period of $12 / 1995$ to $12 / 1996$ six specimens of Myleus tiete Eigenmann \& Norris, 1900 (Osteichthyes: Characidae), with $142.6 \pm$ $24.7 \mathrm{~g}$ weight and $17.3 \pm 1.0 \mathrm{~cm}$ total length, were collected bimonthly with the aid of a net.

This work was developed in the hydroelectric power station of Volta Grande Reservoir (Cemig), MG, Brazil in which presents an inundated area of $195 \mathrm{~km}^{2}$.

Nematodes were carefully collected from the intestinal lumen and fixed in AFA $65^{\circ} \mathrm{C}$ to posterior preservation in alcohol $70 \%$ with $5 \%$ of glycerine. The authors studied 22 males, 22 females and 22 imature females.

Five females were dissected for the measurement of eggs. Helminths were dehydrated and cleared in acetic acid, Amann lactophenol or glycerine. En face preparations followed Chitwood \& Wehr (1934) and the drawings were done in camera lucida. Parasite identification was according to Petter \& Quentin (1976) and Anderson \& Lim (1996).

All measurements are given in milimeters with average and variation in parentheses.

\section{RESULTS}

Only six specimens (three males and three females) of M. tiete were collected in the studied period in which five parasitized with nematodes in the intestine (prevalence 83.3\%). Five out six examined fishes showed an average number of parasites of $535.6 \pm$ 334.6 varying from 134 to 1,088 per fish.

\section{Description: Ichthyouris voltagrandensis n.sp.} (Nematoda: Pharyngodonidae)

Cylindrical nematode, small, whitish colour, cuticle transversely striated. Caudal alae present in males. Lateral alae absent in both sexes. Tail of both sexes narrowing posteriorly with terminal spike. Mouth triangular with four large papillae and two lateral amphids. Demarcated pharynx. Esophagus with corpus, isthmus and terminal bulb. Esophageal bulb with sclerotized valves. Short isthmus in mature female. Long isthmus in imature female. Nerve ring involving the corpus. A large excretory pore placed below the bulb. Females with opisthodelphic uteri (uteri posteriorly directed according to Maggenti, 1981). Elliptical eggs provided with two very long unilateral filaments. One spicule in males. Gubernaculum absent.

Male: body with 1.60 (1.10-1.80) total length by $0.109(0.070-0.152)$ width. Corpus with 0.276 (0.180-0.340) length by $0.030(0.020-0.042)$ width. Isthmus with $0.019(0.010-0.030)$ length by 0.018 (0.010-0.024) width. Terminal bulb with 0.079 (0.060-0.094) length by 0.077 (0.044-0.110) width. Nerve ring $0.166(0.130-0.230)$ and excretory pore 0.494 (0.280-0.640) from anterior extremity. One arcuate spicule with $0.042(0.035-0.048)$ length by 0.005 (0.003-0.007) width. The distance of the testis reflexion to the anterior extremity is $0.633(0.480$ 0.760). Flagellate spermatozoa stored in a spermatheca measuring 0.024 (0.021-0.025) length by $0.004(0.003-0.005)$ width. Tail including caudal spike 0.177 (0.118-0.232) length. Cuticularized platelike structures surrounding the cloacal opening is present. Lateral caudal alae with $0.062(0.057-0.070)$ length by $0.023(0.010-0.033)$ width. Three pairs of genital papillae: one pair of preanal elongate papillae inserted in the caudal alae; two postanal, one pair of strong and pedunculate papillae just posteriorly to cloaca and one pair of small papillae situated posteriorly to the pedunculate papillae. Pedunculate papillae with $0.026(0.016-0.033)$ length.

Female: body with 3.40 (3.00-3.80) total length by $0.306(0.200-0.760)$ width. Corpus with 0.449 (0.350-0.490) length by $0.072(0.064-0.080)$ width. Indistinct isthmus with $0.003(0.002-0.006)$ length by $0.037(0.030-0.040)$ width. Terminal bulb with $0.116(0.096-0.130)$ length by $0.130(0.100-0.144)$ width. Nerve ring $0.187(0.130-0.224)$ and excretory pore $0.856(0.780-0.984)$ from anterior extremity. The distance of the vulva is $1.425(0.840-1.680)$ from 
anterior extremity. Genital tube postpudendum (according to Maggenti, 1981). Ovijector with 0.219 (0.184$0.270)$ length by $0.054(0.040-0.060)$ width. One ovary anterior to the level of vulva and other posterior. The growth zone of ovary presents a reflexion 0.946 (0.792-1.104) from anterior end. Tail including caudal spike $0.420(0.336-0.816)$ length. Phasmids situated $0.349(0.318-0.400)$ from posterior end. From dissected females the eggs enclosed in the uterus measured $0.117(0.112-0.125)$ length by $0.034(0.029$ $0.037)$ width.

Imature female: body with $1.80(1.30-2.80)$ total length by $0.126(0.056-0.240)$ width. Corpus with $0.297(0.196-0.530)$ length by $0.036(0.020$ $0.076)$ width. Isthmus with 0.017 (0.004-0.026) length by $0.020(0.010-0.040)$ width. Terminal bulb with $0.072(0.050-0.116)$ length by $0.079(0.050$ $0.130)$ width. Nerve ring $0.162(0.120-0.336)$ and excretory pore $0.444(0.110-0.764)$ from anterior extremity. The distance of the vulva is 0.835 (0.6001.184) from anterior extremity. Tail including caudal spike $0.297(0.176-0.390)$ length. Phasmids situated $0.210(0.150-0.260)$ from posterior end. The inicial formation of genitalia presents prolongations to the anterior and posterior end of the helminth.

\section{Taxonomic summary}

Type host: Myleus tiete Eigenmann \& Norris, 1900 (Osteichthyes: Characidae).

Site of infection: intestine. Brazil.

Type locality: Volta Grande Reservoir, MG,

Specimens deposited: Coleção Helmintológica do Instituto Oswaldo Cruz (CHIOC), Rio de Janeiro (Holotype male: 33852 a; Allotype female: 33852 b; Paratypes: 33852 c, d).

\section{REMARKS}

Considerable differences in egg size and morphology, as well as buccal papillae were observed when compared with I. ro Inglis, 1962 and I. bursata Moravec \& Prouza, 1995. The most important feature is the absence of lateral alae in both sexes. All species are provided by lateral alae. I. voltagrandensis n.sp. showed similar morphology with I. brasiliensis Moravec et al., 1992a and I. laterifilamenta Moravec et al., 1992b. The eggs of I. laterifilamenta are provided by lateral filaments while the studied eggs of I. voltagrandensis n.sp. showed two filaments in just one pole. In males, the absence of lateral alae and higher measures of tail and caudal alae diferentiate the new species of I. brasiliensis (Table 1). In addition, some characters of females such as width, isthmus length and distance of excretory pore from anterior end were shorter than the described species (Table 2).

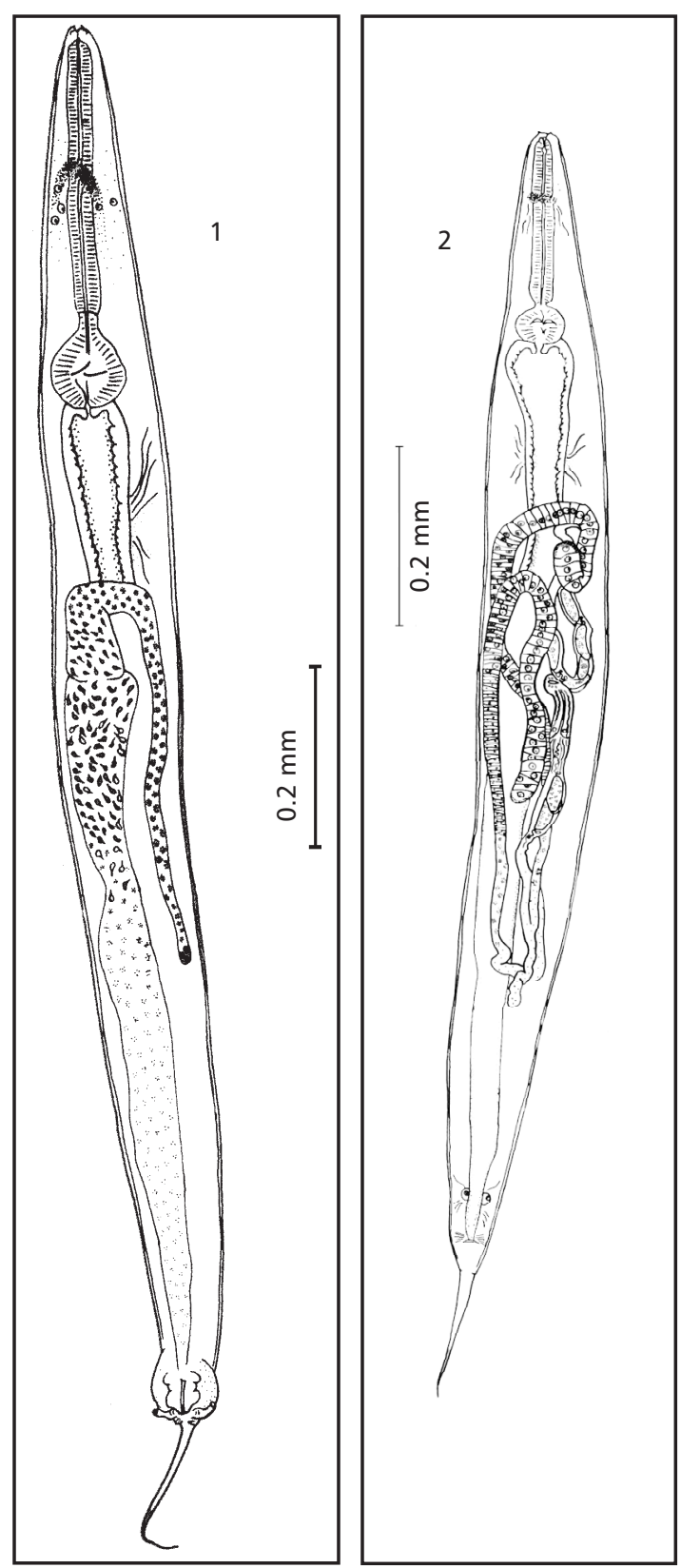

Figs. 1-2 - Ichthyouris voltagrandensis n.sp. 1 - Male. 2 - Adult female. 


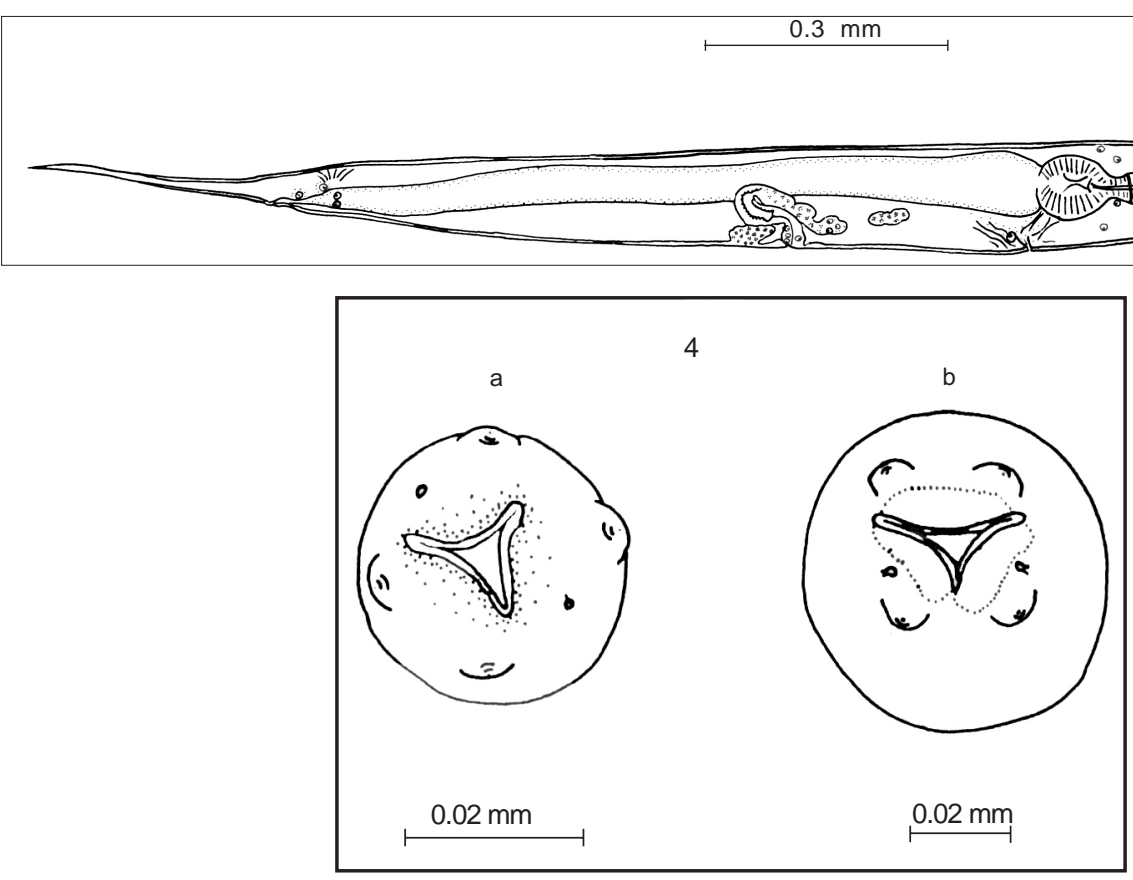

Figs. 3-4 - Ichthyouris voltagrandensis n.sp. 3 - Imature female. 4 - Apical view of the buccal cavity of male (a) and female (b).
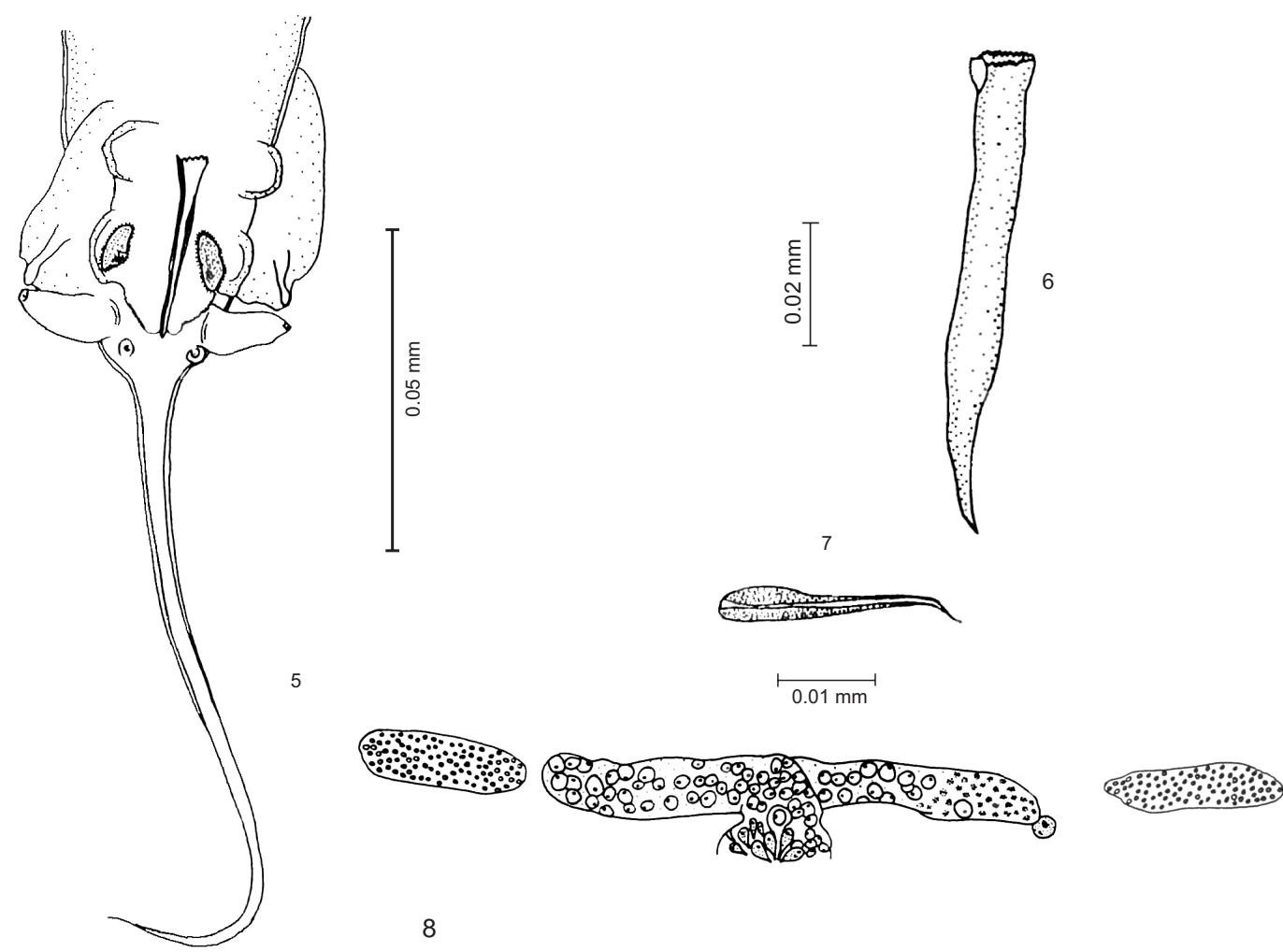

8

$0.1 \mathrm{~mm}$

Figs. 5-8 - Ichthyouris voltagrandensis n.sp. 5 - Caudal end of male. 6 - Lateral view of spicule. 7 - Lateral view of spermatozoa. 8 - Genital tube of female in the beggining of development. 

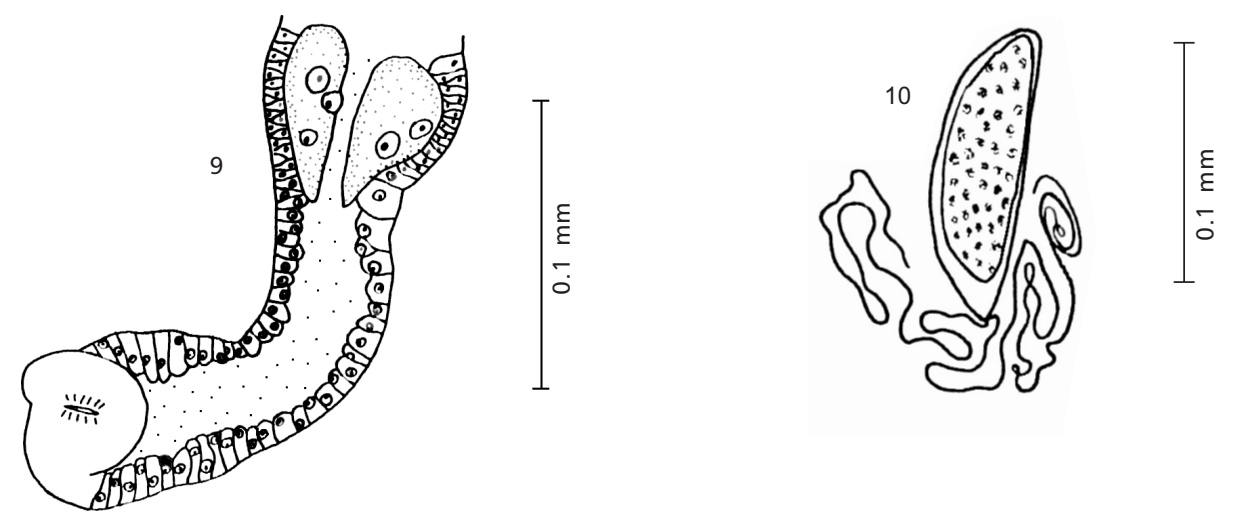

Figs. 9-10 - Ichthyouris voltagrandensis n.sp. 9- Ovijector of an adult female. 10 - Egg showing two filaments in one pole.

TABLE 1

Comparative measures of males of Ichthyouris genus.

\begin{tabular}{|l|c|c|c|c|c|}
\hline & I. ro & I. brasiliensis & I. laterifilamenta & I. bursata & I. voltagrandensis \\
\hline Inglis (1962) & $\begin{array}{c}\text { Moravec } \text { et al. } \\
(1992 \mathrm{a})\end{array}$ & $\begin{array}{c}\text { Moravec } \text { et al. } \\
(1992 \mathrm{~b})\end{array}$ & $\begin{array}{c}\text { Moravec \& Prouza } \\
(1995)\end{array}$ & Present work \\
\hline Width & $0.830-1.100$ & $1.280-1.880$ & $1.160-1.440$ & 1.390 & $1.100-1.800$ \\
\hline Corpus length & $0.057-0.087$ & $0.109-0.150$ & $0.082-0.109$ & 0.109 & $0.070-0.152$ \\
\hline Corpus width & - & $0.024-0.030$ & $0.018-0.024$ & 0.174 & $0.180-0.340$ \\
\hline Isthmus length & - & $0.015-0.018$ & $0.012-0.015$ & 0.015 & $0.020-0.042$ \\
\hline Isthmus width & - & $0.018-0.021$ & 0.015 & 0.015 & $0.010-0.030$ \\
\hline Bulb length & $0.053-0.067$ & $0.063-0.072$ & $0.054-0.063$ & 0.069 & $0.010-0.024$ \\
\hline Bulb width & $0.046-0.058$ & $0.063-0.075$ & $0.048-0.057$ & 0.069 & $0.060-0.094$ \\
\hline Excretory pore ${ }^{1}$ & $0.210-0.280$ & $0.354-0.571$ & $0.375-0.456$ & 0.092 & $0.044-0.110$ \\
\hline Nerve ring & $0.100-0.110$ & $0.135-.0162$ & $0.111-0.135$ & 0.132 & $0.280-0.640$ \\
\hline Spicule length & $0.047-0.049$ & $0.060-0.069$ & $0.036-0.045$ & 0.060 & $0.130-0.230$ \\
\hline Spicule width & - & - & - & - & - \\
\hline Gonads ${ }^{2}$ & - & - & - & $0.035-0.048$ \\
\hline Tail length & $0.217-0.221$ & $0.099-0.138$ & $0.063-0.087$ & $0.003-0.007$ \\
\hline
\end{tabular}

1. Distance of the structure from the anterior extremity. 2. Distance of the testis reflexion to the anterior extremity.

However, an important difference between I. brasiliensis and the present description was spicule length, tail, caudal alae length, the presence of lateral alae and disposition of genital papillae. Comparing with mature females, the distance of vulva from anterior end and isthmus length were smaller than the I. voltagrandensis n.sp.

The eggs of I. brasiliensis females is provided by several filaments in both poles while the new suggested species is provided by two filaments in just one pole.
Moreover, this is the first observation of flagellate spermatozoa from dissected males of the genus Ichthyouris.Due to such differences the authors suggests the name Ichthyouris voltagrandensis n.sp. proposed from the type locality.

Acknowledgments - We are gratefull to Companhia Energética de Minas Gerais - CEMIG, MG, by the finnancial support and to Gastão Reis for the correction of the translation of the manuscript. 
TABLE 2

Comparative measures of females of Ichthyouris genus.

\begin{tabular}{|c|c|c|c|c|c|}
\hline & I. ro & I. brasiliensis & I. laterifilamenta & I. bursata & I. voltagrandensis \\
\hline & Inglis (1962) & $\begin{array}{l}\text { Moravec et al. } \\
\quad \text { (1992a) }\end{array}$ & $\begin{array}{l}\text { Moravec et al. } \\
\quad(1992 b)\end{array}$ & $\begin{array}{c}\text { Moravec \& Prouza } \\
\text { (1995) }\end{array}$ & Present work \\
\hline Total length & $2.100-2.400$ & $3.160-4.500$ & $2.560-3.330$ & $2.390-3.170$ & $3.000-3.800$ \\
\hline Width & $0.150-0.190$ & $0.231-0.422$ & $0.190-0.299$ & $0.231-0.340$ & $0.200-0.760$ \\
\hline Corpus length & $0.490-0.560$ & $0.387-0.435$ & $0.345-0.387$ & $0.300-0.330$ & $0.350-0.490$ \\
\hline Corpus width & - & $0.060-0.078$ & $0.039-0.048$ & $0.045-0.060$ & $0.064-0.080$ \\
\hline Isthmus length & - & $0.006-0.009$ & $0.009-0.012$ & - & $0.002-0.006$ \\
\hline Isthmus width & - & $0.012-0.036$ & $0.027-0.033$ & - & $0.030-0.040$ \\
\hline Bulb length & $0.114-0.116$ & $0.120-0.135$ & $0.087-0.105$ & $0.111-0.126$ & $0.096-0.130$ \\
\hline Bulbo width & $0.102-0.112$ & $0.126-0.159$ & $0.090-0.114$ & $0.120-0.141$ & $0.100-0.144$ \\
\hline Excretory pore $^{1}$ & $0.500-0.590$ & $0.625-0.993$ & $0.625-0.707$ & $0.687-0.707$ & $0.780-0.984$ \\
\hline Nerve ring ${ }^{1}$ & $0.130-0.150$ & $0.165-0.198$ & $0.159-0.168$ & $0.120-0.165$ & $0.130-0.224$ \\
\hline Tail length & $0.410-0.520$ & $0.639-0.870$ & $0.480-0.600$ & $0.321-0.449$ & $0.336-0.816$ \\
\hline Vulva $^{1}$ & $0.850-0.980$ & $1.130-1.650$ & $0.857-0.938$ & $0.898-1.170$ & $0.840-1.680$ \\
\hline Gonads $^{2}$ & - & - & - & & $0.792-1.104$ \\
\hline Ovijector length & - & - & - & - & $0.184-0.270$ \\
\hline Ovijector width & - & - & - & - & $0.040-0.060$ \\
\hline Eggs length & 0.036 & 0.093-0.099 & $0.117-0.138$ & $0.105-0.111$ & $0.112-0.125$ \\
\hline Eggs width & 0.011 & $0.033-0.036$ & $0.051-0.069$ & $0.039-0.042$ & $0.029-0.037$ \\
\hline
\end{tabular}

1. Distance of the structure from the anterior extremity. 2. Distance of the ovary reflexion to the anterior extremity.

\section{REFERENCES}

ANDERSON, R. C. \& LIM, L. H. S., 1996, Synodontisia moraveci n.sp. (Oxyuroidea: Pharyngodonidae) from Osteochilus melanopleurus (Cyprinidae) of Malaysia, with a review of pinworms in fish and a key to species. Syst. Parasitol., 34: 157-162.

CHITWOOD, R. G. \& WEHR, E. E., 1934, The value of cephalic structures as characters in nematode classification, with special reference to the Spiruroidea. Z. Parasitenk., 7: 273-335.

INGLIS, W. G., 1962, Ichthyouris ro gen. et sp. nov. (Nematoda): na oxyurid from a freshwater fish. J. Helminthol., 36(1/2): 45-50.

MAGGENTI, A., 1981, General Nematology. SpringerVerlag, New York, 372p.
MORAVEC, F., KOHN, A. \& FERNANDES, B. M. M., 1992a, Three new species of oxyuroid nematodes, including two new genera, from freshwater catfishes in Brazil. Syst. Parasitol., 21: 189-201.

MORAVEC, F., KOHN, A. \& FERNANDES, B. M. M., 1992b, Nematode parasites of fishes of the Paraná River, Brazil. Part 1. Trichuroidea, Oxyuroidea and Cosmocercoidea. Folia Parasitologica, 39: 327-353.

MORAVEC, F. \& PROUZA, A., 1995, Ichthyouris bursata n.sp. (Nematoda: Oxyuroidea) from an aquarium-reared discus, Symphysodon discus (Pisces), in Europe. Parasite, 2: $385-390$.

PETTER, A. J. \& QUENTIN, J. C., 1976, Keys to genera of the Oxyuroidea. In: R. C. Anderson, A. G. Chabaud \& S. Willmott, CIH keys to the nematode parasites of vertebrates. Commonwealth Agricultural Bureaux, London. 